\title{
STRATEGI KEPALA SEKOLAH \\ DALAM MENINGKATKAN MUTU PENDIDIKAN ISLAM (Studi Kasus di MAS JAM'IYYAH ISLAMIYYAH Pondok Aren)
}

\author{
Ahmad Masruri \\ STIT Al-Amin Kreo Tangerang \\ E-mail: masruriahmad117@gmail.com
}

\begin{abstract}
ABSTRAK
Penelitian ini membahas tentang strategi kepala sekolah dalam meningkatkan mutu Pendidikan Islam di MAS Jam'iyyah Islamiyyah Pondok Aren. Dunia pendidikan khususnya pendidikan Islam semakin dihadapkan kepada berbagai tantangan yang cukup berat. Karena umat Islam hidup di era modern yang penuh dengan tantangan dan sekaligus peluang. Lembaga pendidikan Islam khususnya madrasah masih mengalami kendala dalam meningkatkan mutu pendidikannya. Hal tersebut bisa dilihat dari berbagai aspek mulai dari tujuan kurikulum, tenaga pendidikan, metodologi pembelajaran, sarana prasarana, dan evaluasi, secara keseluruhan masih mengandung permasalahan yang hingga kini belum dapat dipecahkan secara tuntas. Untuk itu dalam meningkatkan mutu pendidikan Islam di madrasah diperlukan leadership yang kuat dari kepala sekolah. Adapun tujuan dari penelitian ini adalah untuk mengevaluasi: 1) usaha kepala sekolah dalam meningkatkan profesionalisme guru, 2) usaha kepala sekolah dalam meningkatkan mutu sarana prasarana pendidikan, 3) usaha kepala sekolah dalam meningkatkan mutu proses pembelajaran, dan 4) usaha kepala sekolah dalam meningkatkan prestasi siswa di MAS Jam'iyyah Islamiyyah Pondok Aren. Penelitian ini menggunakan metode dan pendekatan deskriptif-kualitatif dengan menggunakan tiga instrumen penelitian, yaitu wawancara, observasi, dan studi dokumentasi. Hasil penelitian menunjukkan bahwa: 1) MAS Jam'iyyah Islamiyyah Pondok Aren sudah mengalami peningkatan mutu yang baik. Dibawah kepemimpinan kepala sekolah yang handal, MAS Jam'iyyah Islamiyyah Pondok Aren kini dapat menjadi salah satu lembaga pendidikan Islam yang berada di garda depan dan mampu menghasilkan output yang berprestasi. 2) Usaha kepala sekolah dalam meningkatkan mutu pendidikan, yaitu: a) meningkatkan profesionalisme guru dengan menciptakan aturan bagi guru, menempatkan guru sesuai kemampuannya, memberi kepercayaan dan motivasi, melakukan pembinaan. b) meningkatkan mutu sarana prasarana melalui pembenahan sarana prasarana, melakukan kerjasama dengan lembaga/instansi lain dalam pengadaan sarana prasarana. c) meningkatkan mutu proses pembelajaran dengan mengembangkan model pendidikan yang Islami, membenahi metode pembelajaran, menata mutu kurikulum. d) meningkatkan prestasi siswa dengan mengadakan kegiatan pemantapan, pelajaran tambahan, kerjasama dengan lembaga bimbingan belajar, membimbing guru agar menciptakan pembelajaran efektif, menciptakan budaya sekolah yang disiplin, menyediakan berbagai ekstrakurikuler, mengirimkan siswa dalam berbagai perlombaan.
\end{abstract}

Kata Kunci: Strategi, Kepala Sekolah, Mutu Pendidikan Islam

96 | Mumtäz Vol. 3 No. 1, Tahun 2019 


\begin{abstract}
This study discusses the principal's strategy in improving the quality of Islamic Education in MAS Jam'iyyah Islamiyyah Pondok Aren. The world of education, especially Islamic education, is increasingly faced with quite severe challenges. Because Muslims live in a modern era full of challenges and opportunities. Islamic educational institutions especially madrassas still experience obstacles in improving the quality of education. This can be seen from various aspects ranging from curriculum objectives, education personnel, learning methodology, infrastructure, and evaluation, as a whole still contains problems that have yet to be completely resolved. For this reason, improving the quality of Islamic education in madrasas requires strong leadership from the principal. The purpose of this study was to evaluate: 1) the principal's efforts to improve teacher professionalism, 2) the principal's efforts to improve the quality of educational infrastructure, 3) the principal's efforts to improve the quality of the learning process, and 4) the principal's efforts to improve student achievements at MAS Jam'iyyah Islamiyyah Pondok Aren. This research uses a descriptivequalitative method and approach using three research instruments, namely interviews, observations, and documentation studies. The results showed that: 1) MAS Jam'iyyah Islamiyyah Pondok Aren has experienced good quality improvement. Under the leadership of a reliable school principal, MAS Jam'iyyah Islamiyyah Pondok Aren can now be one of the institutions of Islamic education that is in the vanguard and capable of producing outputs that excel. 2) The principal's efforts in improving the quality of education, namely: a) increasing teacher professionalism by creating rules for teachers, placing teachers according to their abilities, giving confidence and motivation, conducting coaching. b) improve the quality of infrastructure facilities through improving infrastructure, collaborating with other institutions / agencies in the procurement of infrastructure. c) improve the quality of the learning process by developing Islamic education models, improving learning methods, managing curriculum quality. d) improve student achievement by holding activities of strengthening, additional lessons, collaboration with tutoring institutions, guiding teachers to create effective learning, creating a disciplined school culture, providing various extracurricular activities, sending students in various competitions.
\end{abstract}

Keywords: Strategy, Principal, Quality of Islamic Education 


\section{PENDAHULUAN}

Saat ini, dunia pendidikan khususnya pendidikan Islam semakin dihadapkan kepada berbagai tantangan yang cukup berat. Karena umat Islam hidup di era modern yang penuh dengan tantangan dan sekaligus peluang. Di era seperti ini umat manusia ditantang agar memiliki bekal pengetahuan, keterampilan, dan pengalaman yang unggul, sehingga mampu bersaing dan merebut berbagai peluang yang ada di hadapannya. Umat manusia saat ini ditantang agar memiliki sikap yang kreatif, inovatif, dinamis, terbuka, demokratis, memiliki etos kerja yang tinggi, serta memiliki keandalan spiritual sebagai alat untuk menangkis berbagai pengaruh negatif (Nata, 2010, hal. 319).

Menyikapi hal tersebut, Nata (2010, hal. 287) berpendapat bahwa madrasah sebagai lembaga pendidikan Islam perlu dipersiapkan untuk masa depan yang lebih baik. Tetapi hingga saat ini masih terdapat sebagian masyarakat Indonesia yang menggambarkan bahwa madrasah adalah sekolah hanya untuk orang-orang yang kurang mampu, letaknya di pedesaan atau dipinggiran kota, bangunannya sederhana dan reyot, gurunya kurang profesional, kurikulumnya hanya mengajarkan ilmu-ilmu keagamaan, sarana dan fasilitasnya serba minim dan tradisional, dan anggarannya jauh dari memadai, manajemennya sangat lemah, namanya kurang dikenal, dan lulusannya kurang bermutu dan tidak memiliki rasa percaya diri untuk bersaing di era globalisasi saat ini.

Berdasarkan hal tersebut, Muhaimin (2011, hal. 109) berpendapat bahwa lembaga pendidikan Islam khususnya madrasah masih banyak yang mutunya belum menggembirakan. Hal tersebut bisa juga kita lihat dari berbagai aspek yang terkait dengan kegiatan pendidikan Islam, mulai dari visi, misi, tujuan, dasar dan landasan pendidikan, tujuan kurikulum, tenaga pendidikan, metodologi pembelajaran, sarana prasarana, evaluasi, dan pembiayaan, secara keseluruhan masih mengandung permasalahan yang hingga kini belum dapat dipecahkan secara tuntas.

Dalam rangka meningkatkan mutu manajemen sekolah, para peneliti manajemen pendidikan tampaknya hanya membagi hasil penelitiannya dengan pendekatan yang diadaptasi dari model industri yang berfokus pada kualitas fungsi administrasi dan layanan. Sebaliknya, kritik terhadap model industri telah melakukan upaya untuk fokus pada kualitas produk inti dari pendidikan berupa pengajaran dan pembelajaran (Becket \& Brookes, 2008, hal. 47).

Berkaitan dengan hal itu, dalam rangka meningkatkan kualitas pendidikan di sekolah/madrasah secara efektif dan efisien, maka perlu didukung oleh sumber daya manusia yang berkualitas pula. Salah satu komponen pendidikan yang paling berperan dalam meningkatkan kualitas atau mutu pendidikan adalah kepala sekolah sebagai pemimpin pendidikan. (Mulyasa, 2009, hal. 24-25). Oleh karena itu kuatnya leadership/kepemimpinan kepala sekolah/madrasah menjadi salah satu strategi untuk meningkatkan kualitas pendidikan di madrasah.

Mengenai makna kepemimpinan, Rasulullah pernah bersabda, "Apabila tiga orang keluar untuk melakukan sesuatu perjalanan, maka hendaklah mereka mengangkat salah seorang diantara mereka sebagai pemimpin." (H.R. Abu Dawud). Hadis tersebut menjelaskan tentang pentingnya kepemimpinan, baik dalam kegiatan, perkumpulan, apalagi dalam lembaga atau organisasi. Nabi menjelaskan bahwa keluarnya tiga orang dalam melakukan sesuatu saja memerlukan pemimpin, apalagi dalam sebuah lembaga atau organisasi yang terdiri dari tiga orang lebih. Betapa besar peran pemimpin dalam Islam, disamping pemimpin sebagai tugas duniawi, dalam Islam pemimpin merupakan sebuah kewajiban yang harus dilaksanakan bagi mereka yang mampu dan akan dimintai pertanggungjawaban sebab dengan seorang pemimpin yang bertanggung jawab, agama akan menjadi tegak (Zazin, 2011, hal. 196-197). 
Maka pada saat ini, masalah mengenai kepemimpinan kepala sekolah/ madrasah merupakan suatu peran yang menuntut persyaratan kualitas kepemimpinan yang kuat. Bahkan telah berkembang menjadi tuntutan yang luas dari masyarakat, sebagai kriteria keberhasilan sekolah diperlukan adanya kepemimpinan kepala sekolah/madrasah yang berkualitas (Wahjosumidjo, 2003, hal. 349).

Zazin (2011, hal. 213-214) berpendapat bahwa kepala sekolah yang efektif diperlukan sebagai sosok yang mampu mempengaruhi dan penggerak menuju pencapaian wujud tujuan pendidikan di sekolah. Kepemimpinan kepala sekolah/madrasah merupakan suatu kemampuan dan kesiapan kepala sekolah/madrasah untuk mempengaruhi, membimbing, dan menggerakkan staf sekolah agar dapat bekerja secara efektif dalam rangka mencapai tujuan pendidikan dan pengajaran yang telah ditetapkan di sekolah/madrasah.

Adanya kepemimpinan kepala sekolah yang baik dan disiplin kerja guru sebagai pendidik dapat menghasilkan motivasi kerja yang tinggi dari guru dalam menerapkan pembelajarannya di sekolah, meningkatkan prestasi akademik dilihat dari kualitas proses pembelajaran di sekolah, prestasi akademik di sekolah dapat ditingkatkan karena kepemimpinan kepala sekolah dan disiplin kerja yang ditunjukkan oleh guru guru yang baik (Supriadi \& Yusof, 2015, hal 124).

Kepemimpinan dan manajemen sekarang memiliki signifikansi global karena pemerintah mengakui pentingnya pendidikan, sehingga mereka dapat bersaing secara efektif dalam ekonomi internasional, dan melihat kepemimpinan yang efektif sebagai kunci peningkatan sekolah. Di banyak bagian dunia, para pemimpin sekolah diberikan status yang ditingkatkan, dan dalam beberapa kasus pelatihan khusus, sebagai pengakuan atas pentingnya mereka (Bush, 2008, hal. 284).

Kepala sekolah harus berkomitmen untuk membangun kapasitas kepemimpinan sekolah dengan menambahkan nilai pada empat dimensi dalam praktik kepemimpinan transformasional yang memupuk pengaruh ideal, motivasi inspirasional, stimulasi intelektual, dan memberikan perhatian individual kepada semua bawahan dengan harapan mereka mendapatkan pekerjaan. kepuasan dan komitmen untuk tugas yang diberikan dan dapat mencapai keunggulan dalam visi dan misi yang ditargetkan oleh sekolah dan Departemen Pendidikan (Abdul Wahab, Fuad, Fuzlina, Ismail, \& Majid, 2014, hal 46).

Oleh karena itu menurut Muhaimin (2011, hal. 107) jika leadership/ kepemimpinan kepala sekolah/madrasah adalah lemah, maka kecenderungan sekolah/madrasah tersebut akan kurang dinamis bahkan stagnan, lulusannya kurang berkualitas dan kaya masalah, yang pada gilirannya kepercayaan masyarakat akan terbatas, serta akan sulit untuk menghimpun kekuatan dan potensi, sehingga madrasah akan sulit berkembang. Sehingga hal tersebut juga berdampak pada tinggi atau rendahnya mutu pendidikan di madrasah.

MAS Jam'iyyah Islamiyyah Pondok Aren sebagai sebuah lembaga pendidikan formal yang bernuansa Islami yang diselenggarakan oleh Yayasan Amin Syarbini (YAS), didirikan pada tahun 1973. Di dalam usahanya untuk meningkatkan mutu pendidikan, menjadi sebuah tantangan bagi MAS Jam'iyyah Islamiyyah Pondok Aren dalam mewujudkan kesinambungan pendidikan yang terjadi dewasa ini yang kerapkali melibatkan unsur life skill, brains storming, dan leadership yang handal.

Seiring waktu dan perkembangannya, Madrasah Aliyah Swasta (MAS) Jam'iyyah Islamiyyah telah banyak menghasilkan lulusan yang berprestasi dalam lingkup pendidikan lanjutan formal dan informal. Hal tersebut didukung dengan sarana prasarana pendidikan yang ada di MAS Jam'iyyah Islamiyyah Pondok Aren seperti keberadaan Pondok Pesantren dengan pola asrama yang disediakan bagi para siswa yang berkeinginan untuk mendalami ilmu-ilmu agama Islam, masjid, laboratorium komputer, perpustakaan, multi media, klinik, laboratorium bahasa, dan lain-lain. Selain itu, juga didukung oleh leadership/kepemimpinan kepala sekolah/madrasah yang kuat. 


\section{METODE}

Di dalam penelitian ini dideskripsikan bagaimana usaha kepala sekolah dalam meningkatkan mutu pendidikan Islam di MAS. Jam'iyyah Islamiyyah Pondok Aren, maka metode dan pendekatan yang digunakan adalah deskriptif kualitatif. Menurut Sugiyono (2012, hal. 181), dengan menggunakan metode kualitatif tersebut, maka data yang diperoleh akan lebih lengkap, mendalam, kredibel, bermakna, sehingga tujuan dari penelitian dapat tercapai. Karena di dalam penelitian ini peneliti ingin menggali lebih dalam berbagai aspek dan informasi mengenai kinerja kepala sekolah dalam kaitannya dengan peningkatan mutu pendidikan di MAS. Jam'iyyah Islamiyyah Pondok Aren.

Adapun tujuan penelitian deskriptif adalah untuk membuat pecandraan secara sistematis, faktual, dan akurat mengenai fakta-fakta dan sifat-sifat populasi atau daerah tertentu. Secara harfiah, penelitian deskriptif adalah penelitian yang bermaksud untuk membuat pencandraan (deskripsi) mengenai situasi-situasi atau kejadian-kejadian (Suryabrata, 2012, hal. 75)

Maka dari itu penelitian ini bertujuan untuk mendeskripsikan secara alami tanpa adanya manipulasi data lapangan terhadap usaha kepala sekolah dalam meningkatkan mutu pendidikan di MAS Jam'iyyah Islamiyyah Pondok Aren. Adapun partisipan utama yang menjadi kunci informasi di dalam penelitian ini adalah kepala sekolah sebagai pemimpin pendidikan. Kemudian untuk melengkapi data juga peneliti mengambil sumber data yaitu beberapa orang guru dan siswa MAS Jam'iyyah Islamiyyah Pondok Aren sebagai partisipan didalam penelitian ini. Untuk memperoleh data yang lengkap, tepat, dan valid, maka di dalam penelitian ini peneliti menggunakan beberapa teknik, yaitu: (1) Wawancara/interview, (2) Observasi, (3) Dokumentasi. Setelah data terkumpul, peneliti melakukan analisis data. Langkahlangkah analisis data yang dilakukan, 1) peneliti mengumpulkan seluruh data hasil pengamatan dan wawancara berupa catatan lapangan, catatan wawancara, catatan diskusi, dan dokumentasi; 2) peneliti melakukan analisis pertama untuk memilah data kedalam kategori; 3) peneliti melakukan analisis kedua di dalam masing-masing kategori; 4) melakukan proses sintesis, yaitu mengolah keseluruhan data untuk merumuskan hasil akhirnya; 5) peneliti membuat simpulan akhir.

\section{HASIL DAN PEMBAHASAN}

Madrasah Aliyah (MAS) Jam'iyyah Islamiyyah adalah sebuah lembaga pendidikan formal sederajat SMP yang bernuansa Islami yang diselenggarakan oleh Yayasan Amin Syarbini (YAS) Kecamatan Pondok Aren Tangerang Selatan mulai tahun 1973. Sebagai lembaga pendidikan Islam, MAS Jam'iyyah Islamiyyah Pondok Aren merupakan perwujudan dari keinginan dan aspirasi masyarakat untuk mendapatkan layanan pendidikan yang berkualitas dan didasari dengan nilai-nilai Islami.

Kepala sekolah/madrasah sebagai pemimpin pendidikan di tingkat madrasah memiliki peranan yang cukup besar dalam meningkatkan mutu pendidikan di madrasah yang menjadi tanggung jawabnya. Demikian halnya dengan Kepala Madrasah Aliyah Jam'iyyah Islamiyyah Pondok Aren yang juga mempunyai tugas dan fungsi penting dalam meningkatkan mutu madrasah yang dipimpinnya.

Adapun berdasarkan tugas dan fungsinya, strategi kepala sekolah/ madrasah dalam meningkatkan mutu pendidikan Islam di MAS Jam'iyyah Islamiyyah Pondok Aren sebagai berikut:

\section{Meningkatkan profesionalisme guru di MAS Jam'iyyah Islamiyyah Pondok Aren}

Seorang guru harus memiliki keprofesionalan di dalam mengajar, karena suatu pekerjaan akan lebih efektif jika dikerjakan oleh orang yang berkompeten didalamnya. 
Apalagi profesi sebagai seorang guru yang bertugas untuk mendidik seorang manusia atau siswa di sekolah.

Dalam meningkatkan profesionalisme guru di MAS Jam'iyyah Islamiyyah Pondok Aren, pertama kepala madrasah menciptakan suatu aturan yang mengikat bagi semua guru. Salah satunya adalah semua guru harus disiplin.

Seperti yang dikemukakan oleh Makawimbang (2011, hal. 134) bahwa guru yang profesional adalah yang memiliki pengalaman mengajar, kapasitas intelektual, moral, keimanan, ketakwaan, disiplin, tanggung jawab, wawasan kependidikan yang luas, kemampuan manajerial, trampil, kreatif, memiliki keterbukaan profesional dalam memahami potensi, karakteristik dan masalah peserta didik serta memiliki kemampuan mengembangkan kurikulum.

Oleh karena itu, perhatian kepala sekolah MAS Jam'iyyah Islamiyyah Pondok Aren terhadap kedisiplinan warga sekolah perlu diterapkan. Agama Islam pun mengajarkan bahwa segala sesuatu harus dilakukan secara rapi, benar, tertib, dan teratur. Adanya aturan intern yang ditetapkan oleh kepala sekolah bagi semua guru seperti datang harus tepat waktu dan jika tidak bisa mengajar harus izin terlebih dahulu, menunjukkan bahwa kepala sekolah memiliki sikap kepemimpinan yang baik sebagai seorang manajer yang memperhatikan orang-orang yang dipimpinnya. Adapun sikap disiplin yang dimiliki dapat mendorong guru untuk bekerjasama dalam mewujudkan visi dan misi sekolah sehingga mutu pendidikan di sekolah dapat meningkat.

Kedua, kepala sekolah melakukan pemantauan terhadap kondisi. Pernyataan tersebut sejalan dengan pendapat yang dikemukakan oleh Suryosubroto (2014, hal. 188) bahwa hal yang perlu dilakukan kepala sekolah sebagai pemimpin adalah mengetahui keadaan/kondisi guru dalam latar belakang kehidupan lingkungan dan sosial ekonominya, hal ini penting untuk tindakan kepemimpinannya.

Maka usaha kepala sekolah MAS Jam'iyyah Islamiyyah Pondok Aren dengan melakukan pemantauan terhadap guru sudah sesuai dengan tugasnya sebagai pemimpin di sekolah, yaitu memperhatikan guru dan membimbingnya agar mampu menjadi guru yang profesional.

Ketiga, usaha kepala sekolah dalam meningkatkan profesionalisme guru di MAS Jam'iyyah Islamiyyah Pondok Aren yaitu dengan melibatkan guru dalam berbagai kegiatan baik di luar maupun di dalam sekolah. Dalam kegiatan tersebut, semua guru ditempatkan pada posisi yang sesuai dengan kemampuan yang dimilikinya.

Mulyasa (2009, hal. 99) mengemukakan bahwa kepala sekolah sebagai manajer harus memberi kesempatan kepada tenaga kependidikan untuk meningkatkan profesinya, dan mendorong keterlibatan seluruh tenaga kependidikan dalam berbagai kegiatan yang menunjang program sekolah.

Berdasarkan pernyataan di atas, maka usaha kepala sekolah MAS Jam'iyyah Islamiyyah Pondok Aren dengan melibatkan semua guru dalam berbagai kegiatan sekolah merupakan suatu strategi dalam meningkatkan profesionalisme guru. Dengan adanya berbagai kegiatan di sekolah maupun diluar sekolah, para guru bisa dengan aktif mengembangkan keprofesionalannya. Selain itu, usaha kepala sekolah tersebut menunjukkan bahwa Kepala Madrasah Aliyah Jam'iyyah Islamiyyah sangat menjunjung tinggi keadilan bagi semua pihak dengan tidak membeda-bedakan status yang dimilikinya.

Keempat, kepala sekolah menanamkan kepada setiap guru untuk memiliki sikap yang ramah, sopan, dan berkompeten didalam segala hal. Seorang guru harus menjadi teladan yang baik bagi para siswanya.

Hal ini sejalan dengan pernyataan Muhaimin (2011, hal. 118) bahwa madrasah lahir berawal dari pesantren atau merupakan pengembangan dari pesantren, sehingga 
nilai-nilai kepesantrenan di madrasah perlu diterapkan. Diantara ciriciri pondok pesantren adalah adanya kiyai dan santri. Sebagai implikasinya, agar mutu pendidikan Islam semakin meningkat maka di madrasah perlu dikembangkan nilai kepesantrenan tersebut. Seperti sebagai kepala madrasah dan guru, perlu memposisikan dirinya sebagai kiyai dan ustad/ustazah, sehingga mereka harus menjadi teladan dan tokoh panutan di madrasah yang selalu menanamkan sikap keagamaan kepada peserta didik.

Berdasarkan hal tersebut di atas, menurut dapat disimpulkan bahwa keberhasilan pendidikan di sekolah sangat ditentukan oleh keberhasilan kepala sekolah dalam mengelola dan memberdayakan seluruh warga sekolah, yaitu termasuk tenaga pendidik/guru. Kepala sekolah perlu menempatkan dirinya seperti seorang kiyai di madrasah yang menjadi teladan baik dan tokoh panutan bagi semua warga madrasah.

Kelima, kepala madrasah memberikan penghargaan kepada guru-guru yang berprestasi, bentuknya macam-macam, bisa dalam bentuk kenaikan jabatan, atau dalam bentuk pemberian keuangan yang lebih, supaya profesionalisme guru meningkat.

Hal ini sejalan dengan pendapat yang dikemukakan oleh Makawimbang (2011, hal. 54) bahwa mewujudkan peningkatan mutu pendidikan di sekolah dapat dilalui salah satunya dengan cara membudayakan memberi penghargaan bagi guru-guru yang berprestasi.

Kinerja kepala sekolah/madrasah MAS Jam'iyyah Islamiyyah Pondok Aren tersebut telah sesuai dengan tugas dan fungsinya sebagai pemimpin, dimana kepala sekolah berusaha memotivasi guru untuk meningkatkan profesionalismenya dalam bekerja di sekolah dengan cara memberikan penghargaan. Selain itu kepala sekolah juga membangun sebuah keterbukaan diantara semua warga sekolah, serta menciptakan suasana kekeluargaan terhadap para guru, staf, dan siswa. Karena dengan hal tersebut akan tercipta sebuah komunikasi yang baik antar semua warga madrasah.

Keenam, usaha kepala sekolah dalam meningkatkan profesionalisme guru dengan melakukan pembinaan bagi guru didalam dan diluar sekolah. Kegiatan pembinaan didalam sekolah seperti diklat dan rapat rutin yang selalu diadakan di sekolah, sedangkan pembinaan diluar sekolah seperti mengirimkan guru dalam berbagai kegiatan yang diselenggarakan oleh Kementerian Agama atau lembaga lain. Misalnya dengan mengirimkan guru untuk mengikuti kegiatan MGMP (Musyawarah Guru Mata Pelajaran), penataran, pelatihan, seminar, dan kegiatan lainnya untuk pengembangan diri serta menambah wawasan para guru di MAS Jam'iyyah Islamiyyah Pondok Aren.

Sejalan dengan hal tersebut, Mulyasa (2012, hal. 67) mengemukakan bahwa cara yang dapat ditempuh dalam meningkatkan profesionalisme guru adalah mengikutsertakan guru dalam kegiatankegiatan, seperti pelatihan, penataran, seminar, workshop, pemagangan, dan pendampingan yang dapat diselenggarakan oleh lembaga pemerintah, perguruan tinggi, atau lembaga non-pemerintah.

Merujuk pada pernyataan yang dikemukakan oleh narasumber dan Mulyasa di atas, maka peneliti menyimpulkan bahwa meningkatkan profesionalisme guru memang harus dilakukan dengan cara mengadakan berbagai program untuk pengembangan profesi guru sebagai tenaga pendidik. Program tersebut bisa diadakan sendiri oleh sekolah atau di luar sekolah.

Ketujuh, kepala sekolah meningkatkan motivasi kerja guru di sekolah. Pemberian motivasi tersebut dilakukan dengan cara memberi penghargaan kepada setiap guru yang berprestasi. Sedangkan bagi guru yang melanggar aturan dan kode etik akan dikenakan sanksi.

Sejalan dengan hal tersebut, Mulyasa (2012, hal. 64) berpendapat bahwa pengembangan guru merupakan pekerjaan yang harus dilakukan oleh kepala sekolah sebagai manajer personalia pendidikan. Salah satu fungsi personalia yang harus 
dilakukan kepala sekolah adalah memotivasi guru untuk mencapai tujuan pendidikan. Kemudian Uray Iskandar (2015, hal. 1027) juga berpendapat bahwa kepala sekolah harus memiliki rasa tanggung jawab yang besar dalam meningkatkan kinerja guru melalui motivasi kerja kepala sekolah.

Peneliti berpendapat bahwa usaha kepala sekolah dengan meningkatkan motivasi kerja guru dengan memberi penghargaan bagi guru yang berprestasi dan sanksi bagi yang melanggar aturan adalah salah satu strategi yang dapat menambah inisiatif guru, kreatifitas, dan semangat berkompetisi para guru. Dengan melihat usaha kepala sekolah tersebut, peneliti berpandangan bahwa kepala sekolah MAS Jam'iyyah Islamiyyah Pondok Aren memiliki rasa tanggung jawab yang besar dan telah menjalankan tugasnya sebagai manajer personalia pendidikan dengan baik.

Berdasarkan hal tersebut dengan melihat berbagai kompetensi yang dimiliki oleh guru dan staf di MAS Jam'iyyah Islamiyyah, maka kebijakan dan kinerja yang dilakukan oleh kepala madrasah dalam mengembangkan profesionalisme guru dan stafnya sudah sesuai dengan tugas dan fungsinya sebagai kepala madrasah.

\section{Meningkatkan mutu sarana prasarana pendidikan di MAS Jam'iyyah Islamiyyah Pondok Aren}

Fasilitas merupakan sarana yang dapat dibilang paling pokok sebagai penunjang keberhasilan sebuah lembaga pendidikan. Ketika sarana prasarana lengkap, otomatis proses belajar mengajarpun akan berlangsung dengan efektif dan efisien. Proses pembelajaran yang efektif memungkinkan kualitas output lembaga pendidikan yang terjamin dan dapat diandalkan di masyarakat. Berdasarkan pengamatan peneliti, Madrasah Aliyah (MAS) Jam'iyyah Islamiyyah Pondok Aren memiliki sarana belajar dan gedung sekolah yang strategis, bersih dan nyaman digunakan sebagai tempat belajar.

Adapun pertama usaha kepala sekolah MAS Jam'iyyah Islamiyyah Pondok Aren dalam meningkatkan mutu sarana prasarana pendidikan dengan menciptakan budaya sekolah yang nyaman dan bersih.

Pernyataan di atas sejalan dengan pendapat yang dikemukakan oleh Faisal Mubarak dalam jurnalnya bahwa upaya untuk meningkatkan mutu sekolah atau madrasah perlu dilakukan salah satunya dengan menciptakan iklim dan budaya sekolah/madrasah yang kondusif (Mubarak, 2015, hal. 14). Kemudian Muhaimin (2011, hal. 105) menyebutkan bahwa budaya sekolah/madrasah yang kokoh merupakan kekuatan bagi sebuah sekolah/madrasah dan ciri bagi sekolah atau madrasah yang berprestasi.

Berdasarkan pada pernyataan di atas, maka dapat disimpulkan bahwa usaha dalam meningkatkan mutu madrasah memang tidak terlepas dari lengkapnya sarana dan prasarana yang menunjang proses kegiatan belajar mengajar di madrasah. Ruang belajar yang nyaman akan menjadikan proses belajar mengajar menjadi lebih efektif sehingga tujuan pembelajaran dapat tercapai. Sedangkan ruang belajar yang sempit dan pengap akan menjadikan proses belajar mengajar menjadi tidak nyaman dan siswa pun tidak bisa mencapai tujuan pembelajaran yang diharapkan. Selain itu, fasilitas seperti laboratorium serta peralatannya, perpustakaan dengan buku yang lengkap, tempat olahraga, dsb. juga menunjang bagi terciptanya proses pembelajaran yang efektif.

Oleh karena itu, usaha kepala MAS Jam'iyyah Islamiyyah dalam meningkatkan mutu sarana prasarana dengan menciptakan budaya sekolah yang nyaman dan bersih, merupakan suatu bentuk perhatian dan pengawasan kepala sekolah terhadap kelengkapan sarana prasarana sekolah. 
Kedua, kepala MAS Jam'iyyah Islamiyyah Pondok Aren terus melakukan pembenahan di sarana, yaitu gedung sekolah ditingkatkan menjadi tiga lantai, dan perbaikan yang lainnya pula.

Kepala sekolah sebagai pemimpin pendidikan di tingkat madrasah memang memiliki peranan yang cukup besar dalam mengembangkan mutu pendidikan di madrasah yang menjadi tanggung jawabnya (Munir, 2010, hal. 16). Kebutuhan utama yang harus dipenuhi oleh kepala sekolah adalah peserta didik harus dapat belajar secara optimal. Untuk itu peserta didik harus diberikan layanan yang prima dan diberikan fasilitas yang baik dan segala fasilitas yang ada di sekolah harus diarahkan pada kegiatan belajar peserta didik (Mulyasa H. , 2012, hal. 44).

Berdasarkan hal tersebut, sarana prasarana pendidikan yang ada di MAS Jam'iyyah Islamiyyah Pondok Aren perlu mendapatkan perhatian yang serius dari kepala sekolah sebagai pemimpin. Pembenahan sarana prasarana merupakan suatu bentuk pengelolaan sarana dan prasarana pendidikan yang dilakukan oleh kepala sekolah MAS Jam'iyyah Islamiyyah Pondok Aren dalam usahanya untuk meningkatkan mutu madrasah. Selain itu, fasilitas yang ada di sekolah harus membuat siswa merasa puas dengan layanan yang diberikan oleh sekolah.

Ketiga, kepala sekolah memperlihatkan ciri khas sekolah/ madrasah dengan mengharuskan peserta didik berpakaian secara Islami dan memakai jas almamater sekolah. Seperti yang dijelaskan oleh Damopolii (2015, hal. 76) bahwa Pendidikan Islam itu membimbing anak didik dalam perkembangan dirinya, baik jasmani maupun rohani menuju terbentuknya kepribadian yang utama pada anak didik nantinya yang didasarkan pada hukum-hukum Islam.

Usaha kepala sekolah tersebut merupakan salah satu bentuk pengembangan budaya agama di madrasah. Pendidikan merupakan upaya untuk mengembangkan potensi diri anak agar memiliki kekuatan spiritual keagamaan, oleh karena itu di lembaga pendidikan Islam seperti madrasah, usaha kepala sekolah untuk mengembangkan budaya agama sangat penting dalam meningkatkan ketaatan beragama siswa.

Keempat, kepala sekolah mencari sebuah nilai tambah bagi sekolah agar terus berkembang lebih maju. Hal tersebut sejalan dengan pendapat yang dikemukakan oleh Rosdianti (2013, hal 100) dalam jurnalnya bahwa sumbersumber dan cara pengadaan sarana dan prasarana yang ada di sekolah disesuaikan dengan kebutuhan dan anggaran yang tersedia. Sumbernya dapat berasal, baik dari pemerintah maupun dari pihak swasta. Cara pengadaannya adalah melalui proses pengadaan anggaran, pengajuan kebutuhan, dan kesepakatan.

Berdasarkan pernyataan di atas, maka untuk meningkatkan mutu sarana prasarana di madrasah, kepala sekolah perlu mencari berbagai peluang dari banyak sumber dalam upayanya untuk mengumpulkan dana bagi usaha melengkapi sarana prasarana pendidikan di madrasah.

Kelima, dalam usahanya untuk meningkatkan mutu sarana prasarana pendidikan, kepala sekolah juga menjalankan perannya sebagai wirausahawan. Oleh karena itu, kepala sekolah MAS Jam'iyyah Islamiyyah Pondok Aren mencoba untuk berinovasi, yaitu dengan melakukan kerjasama dengan lembaga/instansi lain dalam pengadaan sarana prasarana, seperti dengan Bank Republik Indonesia (BRI), Safiya (perusahaan air mineral), dan Rumah Makan Babakayas.

Sejalan dengan hal tersebut, Rohiat (2009, hal. 91) mengemukakan bahwa strategi yang dapat dilakukan untuk meningkatkan dan mengembangkan sarana prasarana pendidikan yaitu melakukan kerjasama dengan lembaga/instansi lain, khususnya dalam pengadaan sarana dan prasarana, melakukan kerjasama dengan lembaga lain. 
Dari pernyataan di atas, dapat disimpulkan bahwa kepala sekolah yang efektif adalah yang menjalankan kepemimpinannya dengan baik dan terus berusaha untuk meningkatkan mutu pendidikan di sekolah yang dipimpinnya. Dengan melihat usaha yang dilakukan kepala sekolah MAS Jam'iyyah Islamiyyah Pondok Aren, maka patutlah ia dijadikan sebagai teladan bagi pemimpin yang lain.

Keenam, kepala sekolah membentuk tim khusus untuk pemeliharaan dan perawatan fasilitas yang ada di sekolah. Rosdianti (2013, hal. 101) berpendapat bahwa sistem pemeliharaan dan perawatan terhadap sarana dan prasarana tersebut dilakukan oleh semua personil sekolah. Sedangkan yang bersifat khusus, pemeliharaan dan perawatan tersebut dilakukan oleh tenaga ahli yang khusus pula.

Berdasarkan hal tersebut, semua warga sekolah perlu untuk memelihara dan merawat sarana prasarana yang ada di sekolah. Karena sarana prasarana adalah penunjang terciptanya pembelajaran yang efektif. Tanpa adanya pemeliharaan dari warga sekolah, sarana prasarana kemungkinan akan rusak yang menyebabkan proses pembelajaran dapat terganggu. Sarana prasarana di MAS Jam'iyyah Islamiyyah Pondok Aren terbilang baik, karena semua warga madrasah mampu menjaganya dengan baik. Selain itu kepala sekolah juga terus berupaya dalam meningkatkan sarana prasarana yang menunjang bagi terciptanya pembelajaran yang lebih baik.

Ketujuh, kepala sekolah banyak mengadakan kunjungan ke sekolah lain untuk melakukan study banding. Dengan melakukan study banding ke sekolah lain, Kepala MAS Jam'iyyah Islamiyyah Pondok Aren dapat mengetahui apa saja kelebihan yang dimiliki oleh sekolah lain dan bisa dijadikan evaluasi bagi sekolah dalam meningkatkan mutu pendidikannya.

\section{Meningkatkan mutu proses pembelajaran di MAS Jam'iyyah Islamiyyah Pondok Aren}

Proses pembelajaran merupakan kegiatan yang paling utama di sekolah/madrasah. Suasana belajar merupakan faktor yang berperan dalam proses pendidikan. Untuk mengetahui pendidikan yang bermutu perlu dikaji mutu dari segi proses, dimana mutu pendidikan berarti keefektifan dan efisiensi seluruh faktor yang berperan dalam proses pendidikan. Oleh karena itu, pengelola pendidikan perlu untuk melakukan upaya dalam meningkatkan mutu proses pembelajaran agar efektif dan efisien (Zazin, 2011, hal. 66).

Prinsip yang ada saat ini untuk meningkatkan nilai pendidikan adalah mengeluarkan upaya untuk perbaikan berkelanjutan, untuk fokus pada kepentingan pemangku kepentingan, dan untuk meningkatkan kepuasan siswa. Kepuasan siswa sering digunakan untuk menilai kualitas pendidikan, di mana kemampuan untuk mengatasi kebutuhan strategis adalah yang terpenting (Cheng, 1990, hal. 13).

Keberhasilan pendekatan semacam itu akan tergantung pada apresiasi organisasi terhadap keanekaragaman budaya dan komitmen terhadap kualitas dalam pemberian layanan. Memenuhi harapan siswa dalam penyampaian fasilitas layanan, mengadakan sesi pelatihan dan seminar tentang kesadaran lintas budaya yang melibatkan semua karyawan sekolah, memperkenalkan metode pengajaran yang efektif menangani berbagai gaya belajar siswa dengan evaluasi kursus reguler untuk mendukung peningkatan berkelanjutan dalam pengajaran adalah di antara strategi inisiatif yang dapat dipertimbangkan oleh sekolah dalam mengatasi keragaman siswa dan peningkatan kualitas secara keseluruhan (Arambewela \& Hall, 2006, hal. 18).

Sebagai implementasinya, Madrasah Aliyah (MAS) Jam'iyyah Islamiyyah sebagai lembaga pendidikan formal sederajat SMP yang berciri khas agama Islam, maka madrasah ini menekankan pola pendidikan dan kecakapan dasar pengajaran yang berintikan nilai-nilai Islami sebagai landasan berperilaku. Untuk meningkatkan mutu 
proses pembelajaran, di sekolah terdapat Kurikulum dan Hasil Belajar (KHB) yang menjelaskan faktor-faktor pemandu pelaksanaan proses pembelajaran, pengajaran, dan penilaian untuk membantu siswa mencapai hasil belajar.

Adapun pertama usaha Kepala MAS Jam'iyyah Islamiyyah Pondok Aren dalam meningkatkan mutu proses pembelajaran yaitu dengan mengadakan kegiatan bagi peningkatan kemampuan mengajar guru. Guru didorong untuk mengikuti banyak pelatihan, seperti mengikuti kegiatan MGMP, kegiatan penataran, seminar, dan sebagainya. Kesempatan untuk mengikuti kegiatan tersebut diberikan kepada setiap guru, karena guru dituntut untuk memiliki kemampuan mengajar yang baik. Oleh karena itu harus memiliki pemahaman dalam mengelola pembelajaran. Kegiatan pelatihan bagi guru tersebut memberikan efek yang positif bagi guru.

Berdasarkan hal tersebut, peningkatan kemampuan mengajar guru merupakan hal yang sangat penting untuk dilakukan oleh kepala sekolah, karena gurulah yang berperan dalam melaksanakan dan menentukan baik tidaknya mutu proses pembelajaran.

Menurut Makawimbang (2011, hal. 75) dalam usaha untuk meningkatkan mutu kinerja guru, kepala sekolah harus meningkatkan kualitas pengajaran guru baik dari segi strategi, keahlian, dan alat pengajaran. Berdasarkan hal tersebut, maka dapat disimpulkan bahwa kepala sekolah harus membimbing guru dalam menggunakan metode pengajaran ketika di kelas. Selain itu para guru dituntut untuk menggunakan teknologi di dalam pembelajaran agar mempermudah proses pembelajaran. Dalam hal ini Kepala MAS Jam'iyyah Islamiyyah Pondok Aren juga berusaha memberikan bimbingan yang baik kepada semua guru dalam mengajar.

Kedua, kepala sekolah melakukan penataan pada mutu kurikulum yang meliputi proses perencanaan, pelaksanaan, serta evaluasinya juga. Adapun dalam meningkatkan mutu pendidikan Islam di MAS Jam'iyyah Islamiyyah Pondok Aren, kurikulum PAI harus dirancang secara khusus sesuai dengan situasi dan kondisi pendidikan siswanya. Khusus untuk mata pelajaran Pendidikan Agama Islam kurikulum yang digunakan adalah kurikulum terbaru, yaitu Kurikulum 2013.

Kurikulum yang dilaksanakan di MAS Jam'iyyah Islamiyyah Pondok Aren harus bersandar pada nilai-nilai pendidikan agama Islam. Dalam hal penataan kurikulum ini, Kepala MAS Jam'iyyah Islamiyyah berusaha membantu para guru dalam penggunaan strategi atau metode yang baik serta menyiapkan materi-materi yang akan diberikan kepada anak didik dengan cara membina guru atau dengan mengikuti pelatihanpelatihan. Selain itu beliau juga membangun komunikasi yang positif diantara para guru dengan berusaha terbuka dalam setiap hal yang berhubungan dengan madrasah. Beliau juga menciptakan suasana kekeluargaan yang baik terhadap para guru dan staf karyawan lainnya.

Ketiga, kepala sekolah menekankan pola pendidikan yang berintikan nilai-nilai Islami sebagai landasannya dalam berperilaku yang sesuai dengan visi dan misi sekolah. Hal ini sesuai dengan visi dan misi MAS Jam'iyyah Islamiyyah sendiri yaitu menjadi lembaga pendidikan yang unggul guna menghasilkan generasi yang bertakwa, berakhlak mulia, berilmu, dan hidup bermasyarakat. Hal tersebut menunjukkan betapa kepala sekolah berusaha untuk menerapkan pola pendidikan yang Islami untuk meningkatkan mutu pendidikan di MAS Jam'iyyah Islamiyyah Pondok Aren.

Keempat, kepala sekolah membimbing para guru untuk berbenah didalam menggunakan metode dan model pembelajaran. Metode yang paling banyak diterapkan oleh guru dalam pembelajaran yaitu visualisasi dengan kerja kelompok (Roll Playing), jadi guru menggunakan model pembelajaran secara kelompok karena memang disesuaikan dengan Kurikulum 2013. 
Metode pengajaran merupakan salah satu komponen pendidikan yang cukup penting untuk diperhatikan. Penyampaian materi dalam arti penanaman nilai-nilai pendidikan sering gagal karena cara yang digunakannya kurang tepat (Syahidin, 2009, hal. 75). Pada dasarnya, metode pendidikan Islam dianggap sangat efektif dalam membina kepribadian anak didik dan memotivasi mereka sehingga nilai-nilai pendidikan dapat tersampaikan (Nahlawi, 1995, hal. 204).

Berdasarkan pendapat di atas, maka dapat disimpulkan bahwa untuk meningkatkan mutu pendidikan Islam di MAS Jam'iyyah Islamiyyah Pondok Aren, kepala sekolah harus berupaya untuk mengarahkan guru dalam melaksanakan metode dan model pembelajaran yang Islami karena dianggap sangat efektif dalam membentuk kepribadian siswa. Kepala sekolah juga harus membina dan mengarahkan caracara penggunaan media dan sarana pendidikan yang mendukung terhadap pembelajaran, sehingga hasil pembinaan dan pengarahan ini setiap guru dapat menggunakan media dan sarana pendidikan tersebut dengan baik dalam pembelajaran.

\section{Meningkatkan prestasi siswa di MAS Jam'iyyah Islamiyyah Pondok Aren}

Kepemimpinan kepala sekolah yang sukses berpengaruh pada prestasi siswa. Kepala sekolah harus memiliki harapan yang tinggi terhadap prestasi peserta didiknya. Untuk itu kepala sekolah harus berusaha untuk meningkatkan prestasi siswa di sekolah. Untuk mewujudkan sekolah/madrasah yang unggul atau berprestasi, maka kita perlu mengetahui terlebih dahulu karakteristik dari sekolah/madrasah yang berprestasi. Adapun menurut Muhaimin (2011, hal. 104-105) karakteristik dari sekolah/madrasah yang berprestasi dilihat dari aspek outputnya yaitu berupa prestasi akademik siswa yang ditunjukkan dengan NUN (Nilai Ujian Nasional), lomba karya ilmiah, lomba mata pelajaran, dan lainlain. Dan juga prestasi nonakademik siswa yang ditunjukkan dengan keingintahuan yang tinggi, kerjasama yang baik, rasa kasih sayang yang tinggi terhadap sesama, toleransi, kedisiplinan, kerajinan, prestasi olahraga dan kesenian, kepramukaan, dan sebagainya.

Apabila dilihat dari hasil pendidikan, mutu pendidikan dipandang bermutu jika mampu melahirkan keunggulan akademik dan ekstrakurikuler pada peserta didik yang dinyatakan lulus untuk satu jenjang pendidikan atau menyelesaikan program pembelajaran tertentu (Minarti, 2011, hal. 330). Dalam rangka mengembangkan sekolah/ madrasah berprestasi, kepala sekolah harus membangun berbagai kekuatan di sekolah/madrasah. Salah satunya yaitu sekolah harus menciptakan siswa yang berprestasi yang dapat membawa nama baik sekolah/madrasah di tingkat nasional bahkan internasional (Muhaimin, 2011, hal. 105).

Orang tua memandang kualitas berkaitan dengan input (Peringkat sekolah, reputasi) dan output (Kemampuan kerja, penempatan akademik). Di sisi lain, siswa melihat kualitas terkait dengan proses pendidikan (Kursus dan pengajaran) dan hasil. Anggota sekolah menganggap kualitas berkaitan dengan keseluruhan sistem pendidikan (yaitu input, proses, dan output). Pengusaha melihat kualitas terutama terkait dengan output seperti Set keterampilan yang dibawa siswa ke tempat kerja (Chua, 2004, hal. 5).

Di MAS Jam'iyyah Islamiyyah Pondok Aren sendiri, dilihat dari output atau hasil lulusannya banyak yang berprestasi baik di bidang akademik maupun nonakademik. Di bidang akademik bisa kita lihat dari banyaknya lulusan MAS Jam'iyyah Islamiyyah Pondok Aren yang bisa menempuh pendidikan lanjutan dan diterima di universitas favorit atau negeri. Sedangkan di bidang non akademik, banyak siswa yang berprestasi dan mendapatkan penghargaan di bidang olahraga dan seni.

Adapun usaha Kepala MAS Jam'iyyah Islamiyyah Pondok Aren dalam meningkatkan prestasi siswa yang pertama, untuk meningkatkan prestasi akademik 
siswa, ketika menjelang Ujian Nasional, langkahnya dengan mengadakan pemantapan, pelajaran tambahan, kerjasama dengan lembaga bimbingan belajar. Hal tersebut sesuai dengan tujuan umum pendidikan di MAS Jam'iyyah Islamiyyah Pondok Aren yaitu peserta didik mampu lulus Ujian Nasional dengan baik dan diterima di jenjang berikutnya sesuai dengan yang diinginkan serta memiliki kemampuan yang lebih baik.

Usaha kepala sekolah tersebut sejalan dengan pendapat Hasbi (2013, hal. 394) bahwa kompetensi lulusan yang tinggi berdasarkan hasil ujian nasional dan output pendidikan di madrasah banyak yang diterima di sekolah favorit merupakan salah satu faktor pendukung peningkatan mutu pendidikan di madrasah.

Mengadakan bimbingan belajar bagi siswa ketika menghadapi Ujian Nasional merupakan cara yang tepat bagi kepala sekolah untuk meningkatkan prestasi akademik siswa. Seperti yang dikemukakan oleh Kepala MAS Jam'iyyah Islamiyyah Pondok Aren bahwa ketika akan menghadapi Ujian Nasional, madrasah mengadakan kerjasama dengan lembaga bimbingan belajar yang berkualitas baik.

Kedua, kepala sekolah memberikan pembekalan kepada guru-guru, dengan harapan nilai Ujian Nasional bisa meningkat. Di dalam meningkatkan prestasi siswa tidak dapat dipungkiri bahwa sumber daya manusia yang paling berpengaruh adalah guru. Oleh karena itu, kepala sekolah harus berusaha membimbing dan mengarahkan guru dalam menciptakan suasana belajar yang efektif. Hal tersebut sesuai dengan yang dikemukakan oleh Suharsaputra (2013, hal. 149-150) bahwa kepala sekolah yang sukses berpengaruh pada prestasi siswa meskipun bersifat tidak langsung jelas akan signifikan bagi pengembangan organisasi sekolah, sebab SDM utama pendidikan yaitu guru akan dapat berkembang dan meningkat diiringi dengan proses organisasi yang makin efektif.

Ketiga, untuk meningkatkan mutu peserta didik, ketika penerimaan siswa baru, ada seleksi terlebih dahulu berupa Tes Baca Tulis Al-Qur'an, wawancara dengan BK kepada peserta didik dan orang tuanya, dan juga tes pengetahuan tertulis. Setiap tahunnya jumlah siswa yang mendaftarkan diri untuk bersekolah di MAS Jam'iyyah Islamiyyah Pondok Aren selalu meningkat dan sekolah juga tidak pernah kekurangan murid. Dengan adanya seleksi tersebut, menunjukkan bahwa MAS Jam'iyyah Islamiyyah Pondok Aren berusaha untuk meningkatkan mutu madrasah agar berkualitas dengan mengadakan seleksi bagi calon peserta didik.

Keempat, kepala sekolah menciptakan budaya sekolah yang disiplin. Dimulai dari pribadi sendiri, para siswa di MAS Jam'iyyah Islamiyyah Pondok Aren ini sedikit sekali ada yang terlambat datang ke sekolah. Dari pukul 06.30 WIB semua warga sekolah sudah berjalan ke mesjid untuk melakukan Sholat Dhuha, tentunya di awali dulu oleh kepala madrasah. Kemudian di MAS Jam'iyyah Islamiyyah Pondok Aren ini siswanya tidak ada yang pernah pulang duluan, meskipun tidak ada guru, karena sudah siap piket, tetap pulang pada waktu yang sudah ditentukan.

Budaya sekolah/madrasah yang disiplin memang harus ada pada setiap lembaga pendidikan. Oleh karena itu usaha Kepala MAS Jam'iyyah Islamiyyah dengan menciptakan madrasah yang disiplin merupakan hal yang sangat baik dan mendukung juga bagi terciptanya pendidikan Islam yang berkualitas. Apalagi dengan adanya aturan yang mengharuskan sebelum memulai pembelajaran semua warga madrasah melaksanakan Sholat Dhuha bersamasama, hal tersebut banyak memberikan dampak yang positif bagi semua warga madrasah.

Kelima, di sekolah disediakan berbagai ekstrakurikuler baik keagamaan seperti Tahsin Al-Qur'an, Marawis, Qosidah, Nasyid, PAI Club maupun ekstrakurikuler umum lainnya. Ada juga ekstrakurikuler yang dilaksanakannya menjelang kegiatan lomba, seperti olimpiade sains. Dari tahun ke tahun ekstrakurikuler juga terus bertambah, seperti Seni tari, teater, dsb. Kegiatan ekstrakurikuler di MAS Jam'iyyah Islamiyyah Pondok 
Aren ini memberikan efek positif bagi sekolah tersebut karena selain dapat menambah wawasan pengetahuan, para siswa juga bisa berlatih dan mengembangkan bakat mereka, misalnya dalam bidang seni baca tulis Al-Qur'an, kaligrafi, ilmu keislaman, dll.

Berdasarkan Peraturan Menteri Pendidikan dan Kebudayaan RI No. 81A Tahun 2013 tentang Implementasi Kurikulum, kegiatan ekstrakurikuler tersebut menjembatani kebutuhan perkembangan siswa yang berbeda, seperti perbedaan kemampuan, kreativitas dan perbedaan sense akan nilai moral dan sikap. Melalui partisipasinya dalam kegiatan ekstrakurikuler siswa dapat belajar dan mengembangkan kemampuan berkomunikasi, bekerja sama dengan orang lain, serta menemukan dan mengembangkan potensinya. Kegiatan ekstrakurikuler juga memberikan manfaat sosial yang besar.

Langkah-langkah tersebut akan membawa bidang ini lebih dekat untuk menilai hubungan yang sebenarnya antara partisipasi dan fungsi remaja dan peran yang dimainkan oleh kegiatan ekstrakurikuler dalam mempromosikan transisi yang berhasil ke masa dewasa muda (Feldman \& Matjasko, 2005, hal. 202)

Usaha kepala sekolah tersebut telah sesuai dengan strategi yang dikemukakan oleh Suharsaputra (2013, hal. 105) dalam meningkatkan prestasi siswa khususnya di bidang keagamaan yaitu sekolah/madrasah harus mengembangkan budaya agama di lingkungan sekolah/madrasah. Berdasarkan hal tersebut, maka dapat disimpulkan bahwa dengan adanya program ekstrakurikuler keagamaan maupun ekstrakurikuler umum lainnya, siswa dapat mengembangkan potensi yang dimilikinya, sehingga prestasi siswa akan semakin meningkat khususnya di bidang non-akademik. Jika output yang dihasilkan oleh MAS Jam'iyyah Islamiyyah Pondok Aren memiliki prestasi yang baik, maka hal tersebut menunjukkan bahwa Kepala MAS Jam'iyyah Islamiyyah Pondok Aren telah berhasil dalam meningkatkan mutu pendidikan Islam dan madrasah tersebut bisa dikatakan memiliki mutu yang baik.

Keenam, di sekolah selalu diadakan lomba khusus. Selain itu, guru banyak melibatkan siswa dalam berbagai kegiatan, baik kegiatan didalam maupun diluar madrasah. Didalam hal ini, untuk meningkatkan mutu pendidikan memang diperlukan komitmen sekolah/madrasah bergerak di bidang mutu siswa, oleh karena itu sekolah/madrasah kerapkali berpartisipasi dalam berbagai lomba di tingkat nasional (Suhardan, 2010, hal. 155). Berdasarkan hal tersebut, maka dapat disimpulkan bahwa usaha Kepala MAS Jam'iyyah Islamiyyah Pondok Aren dalam meningkatkan prestasi siswa dengan mengikutkan siswa dalam berbagai perlombaan baik kurikuler maupun ekstrakurikuler, sudah sesuai dengan tugas dan fungsinya.

\section{KESIMPULAN}

Hasil penelitian di lapangan menunjukkan bahwa strategi yang dilakukan kepala sekolah dalam meningkatkan mutu pendidikan Islam di MAS Jam'iyyah Islamiyyah Pondok Aren berjalan dengan baik. Dibawah kepemimpinannya, Madrasah Aliyah Jam'iyyah Islamiyyah Pondok Aren yang tadinya sulit untuk berkembang, kini madrasah tersebut menjadi salah satu lembaga pendidikan Islam yang berada di garda depan dan mampu menghasilkan output yang berprestasi dan memiliki akhlak yang sesuai dengan nilai-nilai keislaman. Hal ini dibuktikan dengan meningkatnya status akreditasi madrasah baru-baru ini dari awalnya baik menjadi sangat baik.

Adapun usaha kepala sekolah dalam meningkatkan mutu pendidikan Islam di MAS Jam'iyyah Islamiyyah Pondok Aren yaitu: pertama dengan meningkatkan profesionalisme guru. Di dalam hal ini, Kepala MAS Jam'iyyah Islamiyyah Pondok Aren telah berhasil dalam meningkatkan profesionalisme guru. Hal tersebut terlihat dari guru-guru di MAS Jam'iyyah 
Islamiyyah Pondok Aren yang rata-rata sudah memiliki kemampuan dasar guru profesional di dalam mengajar. Mereka memiliki latar belakang pendidikan yang baik, yaitu S1, S2, dan bahkan ada juga yang doctor. Mereka juga memiliki pengalaman mengajar yang baik, wawasan pendidikan yang luas, disiplin, dan tanggung jawab. Hal ini bisa dilihat ketika observasi di kelas, guru yang mengajar begitu antusias dan mampu mengambil hati para siswa untuk serius dalam belajar. Sehingga proses pembelajaran terlihat efektif dan efisien.

Melihat berbagai kompetensi yang dimiliki oleh guru dan staf di MAS Jam'iyyah Islamiyyah, maka kebijakan dan kinerja yang dilakukan oleh kepala madrasah dalam mengembangkan profesionalisme guru dan stafnya sudah sesuai dengan tugas dan fungsinya sebagai kepala madrasah.

Kedua, meningkatkan mutu sarana dan prasarana pendidikan; Kepala MAS Jam'iyyah Islamiyyah Pondok Aren terus melakukan pembenahan di sarana, yaitu gedung sekolah ditingkatkan menjadi tiga lantai, dan perbaikan yang lainnya pula. Pembenahan sarana prasarana tersebut membuat siswa merasa puas dengan layanan yang diberikan oleh sekolah.

Ketiga, peningkatan mutu proses pembelajaran; Untuk meningkatkan mutu proses pembelajaran, MAS Jam'iyyah Islamiyyah Pondok Aren merancang Kurikulum dan Hasil Belajar (KHB) yang didalamnya menjelaskan faktor-faktor yang memandu pelaksanaan proses pembelajaran, pengajaran, dan penilaian untuk membantu siswa mencapai hasil belajar.

Keempat, peningkatan prestasi siswa; Para siswa di MAS Jam'iyyah Islamiyyah Pondok Aren memiliki prestasi yang sangat baik. Di bidang akademik dibuktikan dengan hasil ujian yang selalu meningkat setiap tahunnya dan banyaknya lulusan MAS Jam'iyyah Islamiyyah Pondok Aren yang bisa menempuh pendidikan lanjutan dan diterima di sekolah favorit atau negeri. Sedangkan di bidang nonakademik, banyak siswa yang berprestasi dan mendapatkan penghargaan di bidang olahraga dan seni. 


\section{DAFTAR PUSTAKA}

Abdul Wahab, J., Fuad, M., Fuzlina, C., Ismail, H., \& Majid, S. (2014). Headmasters' transformational leadership and their relationship with teachers' job satisfaction and teachers' commitments. International Education Studies, 7(13), 40-48.

Arambewela, R., \& Hall, J. (2006). A comparative analysis of international education satisfaction using SERVQUAL. Journal of Services Research, 6(Special), 141-163.

Becket, N., \& Brookes, M. (2008). Quality management practice in higher education-What quality are we actually enhancing? Journal of Hospitality, Leisure, Sports and Tourism Education (Pre-2012), 7(1), 40.

Buhungo, R. A. (2015). Implementasi dan Pengembangan Kurikulum 2013 pada Madrasah Aliyah. TADBIR Jurnal Manajemen Pendidikan Islam , 3, 105-113.

Bush, T. (2008). From management to leadership: semantic or meaningful change? Educational Management Administration \& Leadership, 36(2), 271-288.

Cheng, Y. (1990). Conception of School Effectiveness and Models of School Evaluation: A Dynamic Perspective. Chinese University Education Journal, 18(1), 47-61.

Chua, C. (2004). Perception of quality in higher education. In Proceedings of the Australian universities quality forum (pp. 181-187). Australian University Quality Agency Melbourne.

Damopolii, M. (2015). Problematika Pendidikan Islam dan Upaya-Upaya Pemecahannya. TADBIR Jurnal Manajemen Pendidikan Islam , 3, 6881.

Feldman, A. F., \& Matjasko, J. L. (2005). The Role of School-Based Extracurricular Activities in Adolescent Development: A Comprehensive Review and Future Directions. Review of Educational Research, 75(2), 159-210.

Hasbi, H. (2013). Peningkatan Mutu Pendidikan Madrasah Dalam Sistem Pendidikan Nasional Di Kota Palopo Tahun 2011-2012. Jurnal Diskursus Islam , 1, 381-395.

Iskandar, U. (2015). Kepemimpinan Kepala Sekolah dalam Peningkatan Kinerja Guru. Jurnal Visi Ilmu Pendidikan , 1018-1027.

Makawimbang, J. H. (2011). Supervisi dan Peningkatan Mutu Pendidikan. Bandung: Alfabeta.

Minarti, S. (2011). Manajemen Sekolah: Mengelola Lembaga Pendidikan Secara Mandiri. Jogjakarta: Ar-Ruzz Media.

Mubarak, F. (2015). Faktor dan Indikator Mutu Pendidikan Islam. Management of Education $, 1,10-18$.

Muhaimin, H. (2011). Pemikiran dan Aktualisasi Pengembangan Pendidikan Islam. Jakarta: Rajawali Pers.

Mulyasa, H. (2012). Manajemen dan Kepemimpinan Kepala Sekolah. Jakarta: Bumi Aksara.

Munir, A. (2010). Menjadi Kepala Sekolah Efektif. Jogjakarta: Ar-Ruzz Media.

Nahlawi, A. A. (1995). Pendidikan Islam di Rumah, Sekolah, dan Masyarakat. Jakarta: Gema Insani.

Nata, A. (2010). Manajemen Pendidikan: Mengatasi Kelemahan Pendidikan Islam di Indonesia (3 ed.). Jakarta: Kencana. 
Rohiat. (2009). Manajemen Sekolah: Teori Dasar dan Praktik. Bandung: PT Refika Aditama.

Rosdianti, S. R. (2013). Kepemimpinan Kepala Sekolah dalam Manajemen Kinerja Guru dan Peningkatan Mutu Pembelajaran: Studi Deskriptif pada Sekolah Menengah Kejuruan Swasta di Kota Bandung. ATIKAN, 3(1).

Sugiyono. (2012). Metode Penelitian Administrasi. Bandung: Alfabeta.

Suhardan, D. (2010). Supervisi Profesional (Layanan dalam Meningkatkan Mutu Pembelajaran di Era Otonomi Daerah). Bandung: Alfabeta.

Suharsaputra, U. (2013). Administrasi Pendidikan. Bandung: PT Refika Aditama

Supriadi, E., \& Yusof, H. (2015). Relationship between Instructional Leadership of Headmaster and Work Discipline and Work Motivation and Academic Achievement in Primary School at Special Areas of Central Jakarta. Journal of Education and Learning, 4(3), 123-135.

Suryabrata, S. (2012). Metodologi Penelitian. Jakarta: Rajawali Pers.

Suryosubroto, B. (2014). Manajemen Pendidikan di Sekolah. Jakarta: PT Rineka Cipta.

Syahidin. (2009). Menelusuri Metode Pendidikan dalam Al-Quran. Bandung: Alfabeta.

Wahjosumidjo. (2003). Kepemimpinan Kepala Sekolah. Jakarta: PT RajaGrafindo Persada.

Zazin, N. (2011). Gerakan Menata Mutu Pendidikan: Teori dan Aplikasi. (M. Sandra, Penyunt.) Jogjakarta: Ar-Ruzz Media 